\title{
A Resource for Planning for Disasters and Outbreaks: Lessons From the West African Ebola Epidemic
}

\author{
Firehiwot Berhane, MD; Alem Mehari, MD; Richard Gillum, MD
}

Key Words: communicable diseases, disaster planning, epidemics, mortality

$\mathrm{T}$ he extent of the West African Ebola virus disease (EVD) epidemic and the role of inadequate preparedness at the national, regional, and international levels has been well documented. ${ }^{1,2}$ Lack of communication and coordination among disaster preparedness and outbreak response agencies contributed to the toll of illness and death. Recent articles in this journal suggest that active efforts are underway in West Africa and Angola to enhance preparedness. ${ }^{3,4}$ A useful resource for response planning is available online, providing multiple measures of disease burden from the 2014-2015 EVD epidemic, as well as country-specific data for over 300 conditions and risk factors. ${ }^{5}$ The Global Burden of Disease (GBD) provides a tool to quantify health loss. GBD has distilled large amounts of complicated information into a suite of interactive data visualizations. For example, the following data for Sierra Leone in 2013-2017 indicate the burden of EVD compared to malaria, the leading cause of death even during the EVD outbreak.

In 2017, in Sierra Leone, the population was 7.8 million, gross domestic product (GDP) per capita was US $\$ 1399$, educational attainment was 3.8 years. Life expectancy at birth was 61.4 years in females and 59.5 years in males. The leading cause of death was malaria followed by lower respiratory infection, neonatal disorders, and diarrheal diseases. The leading causes of premature deaths were malaria, neonatal disorders, and diarrheal diseases. Total health care spending per person was US $\$ 82$. The estimated number of deaths from all causes, malaria, and EVD, respectively, were 2013 (73 425, 11 190, 0); 2014 (77 362, 10269,5207$) ; 2015$ (74 220, 10 567, 2397); 2016 (71 398, 11 164, 2); and 2017 $(71227,11119,0)$. In 2014, EVD caused $7.1 \%$ of total deaths and, in $2015,3.2 \%$. In comparison, malaria caused $13.3 \%$ in 2014 and $14.2 \%$ in 2015. When there was no EVD, in 2013, malaria caused $15.2 \%$ and, in $2017,15.6 \%$ of deaths.

In conclusion, disaster preparedness and outbreak response agencies working jointly to prepare for future EVD epidemics can use GBD data to enhance the planning process.

\section{About the Authors}

Howard University Hospital, Washington, DC (Drs Berhane, Mehari); Howard University College of Medicine, Washington, DC (Drs Mehari, Gillum).

Correspondence and reprint requests to Firehiwot Berhane, Howard University Hospital, 2045 Georgia Avenue NW, Washington, DC 20060 (e-mail: firehiwot@gmail.com).

\section{Conflict of Interest Statement}

The authors have no conflicts of interest to declare.

\section{REFERENCES}

1. Spengler JR, Ervin ED, Towner JS, et al. Perspectives on West Africa Ebola virus disease outbreak, 2013-2016. Emerg Infect Dis. 2016;22(6):956-963. doi: 10.3201/eid2206.160021.

2. Marston BJ, Dokubo EK, van Steelandt A, et al. Ebola response impact on public health programs, West Africa, 2014-2017. Emerg Infect Dis. 2017;23(13). doi: 10.3201/eid2313.170727.

3. Morton Hamer MJ, Reed PL, Greulich JD, Beadling CW. Economic community of West African states disaster preparedness tabletop exercise: building regional capacity to enhance health security. Disaster Med Public Health Prep. 2019;13(3):400-404. doi: $10.1017 / \mathrm{dmp} .2018 .44$.

4. Owens MD, Rice J. The Angolan Pandemic Rapid Response Team: an assessment, improvement, and development analysis of the first self-sufficient African National Response Team curriculum. Disaster Med Public Health Prep. 2019;13(3):577-581. doi: 10. 1017/dmp.2018.122.

5. Institute for Health Metrics and Evaluation (IHME). [Sierra Leone] profile. Seattle, WA: IHME, University of Washington. 2018. http:// www.healthdata.org/ [SierraLeone]. Accessed August 30, 2019. 